\title{
A New Frontier in International Investment Law: Adjudication of Host Citizen-Investor Disputes?
}

\author{
Martin Jarrett* \\ Max Planck Institute for Comparative Public Law and International Law, \\ Heidelberg, Germany \\ jarrett@mpil.de
}

Abstract

Keywords

I. Introduction

II. The Normative Case for the International Adjudication of Host Citizen-Investor

Disputes

1. Practical Factors Inhibiting Access to Justice for Host Citizens

2. Legal Factors Inhibiting Access to Justice for Host Citizens

3. Assessment of the Normative Case for International Adjudication of Host CitizenInvestor Disputes

III. The Politics of Instituting the International Adjudication of Host Citizen-Investor Disputes

IV. Critical Analysis of Proposals for the International Adjudication of Host Citizen-

Investor Disputes

1. Legal Issue 1: Identity of the Investor

2. Legal Issue 2: Applicable Substantive Law

3. Legal Issue 3: State-Compelled Consent of Investor

4. Impracticalities of the International Adjudication of Host Citizen-Investor Disputes

V. Other Options for Facilitating Access to Justice for Host Citizens 994

1. Ombudspersons and Better Access to Domestic Courts 994

2. Mandatory Insurance Scheme for Host Citizen-Investor Disputes 996
a) Legal Issues
997

b) Practical Issues

998

VI. Conclusion

999

\footnotetext{
* Senior Research Fellow, Max Planck Institute for Comparative Public Law and International Law. Draft versions of this article were presented at the workshops 'The Legitimacy of International Investment Law and Arbitration in Protecting Human Rights' (PluriCourts, University of Oslo) and 'The Value of Solidarity in International Economic Law' (Workshop of the ESIL IEL IG at the 2021 ESIL Catania Research Forum). I am grateful to the organisers of those workshops for giving me the opportunity to present there and the commentators who offered their considered thoughts on my initial drafts, namely Prof. Marina Trunk Fedorova and Dr. Anil Yilmaz Vastardis. Finally, I thank the anonymous peer-reviewer for their valuable critique and suggestions. All errors are my own.
} 


\section{Abstract}

This is the age of reform in the world of international investment law. Most particularly through the reform process at the United Nations Commission on International Trade Law (UNCITRAL), states are seeking to remake the procedural infrastructure of international investment law for it to better respond to their interests. One new addition to the existing infrastructure that has been proposed is making investors accountable at the international level for their misconduct. Under this rubric, the idea of giving host citizens the possibility of claiming against investors in international adjudication has been mooted.

Scholars have been quick to draw up proposals for the international adjudication of host citizen-investor disputes. This paper examines the legal challenges and practical difficulties with those proposals. On the back of that examination, it is concluded that the European Union-proposed Multilateral Investment Court could serve as a forum for the international adjudication of host citizen-investor disputes. But it would only play a supporting role in a bigger system of justice for host citizens. The main role would be played by a mandatory insurance scheme. This paper puts forward the first conception on how this scheme could work in tandem with the Multilateral Investment Court to deliver justice on a broad scale to host citizens.

\section{Keywords}

Host Citizen-Investor Disputes - Business and Human Rights - International Adjudication at Multilateral Investment Court

\section{Introduction}

The historical significance of the reform process for investor-state dispute settlement (ISDS) under the auspices of UNCITRAL cannot be overstated. The reformed procedural infrastructure for ISDS that emerges from it will likely stay in place for decades to come. This likelihood has not been lost on the delegations at UNCITRAL. For this reason, they are putting on the negotiating table all of their ideas on the future look of ISDS. One idea gaining traction is granting rights of standing to states, most particularly through the embedding of counterclaims or, even more ambitiously, direct 
actions against investors in the new architecture. But South Africa is ready to go one step further by: ${ }^{1}$

'Allowing [...] other affected individuals or communities to bring claims against investors.'

The attractions of this idea of international adjudication of host citizeninvestor disputes are readily apparent. First, as in many state-investor disputes the state is practically representing host citizens who are actually affected by some investor misconduct, ${ }^{2}$ giving host citizens the possibility to take action against investors themselves would depoliticise the matter of a state bringing of a claim (for the affected citizens) against an investor. This idea of depoliticisation is, of course, a traditional justification for giving investors the possibility to directly initiate claims against states under investment treaties. ${ }^{3} \mathrm{~A}$ second factor explaining the attraction is access-to-justice problems in domestic courts. Most particularly for host-citizen claimants in the developing world, and even more so in least-developed states, ${ }^{4}$ gaining access to justice in courts for disputes with investors will oftentimes be difficult.

On account of these factors, some scholars have begun to design the features of the procedural infrastructure that could accommodate host citizen-launched claims against investors. Two designs have emerged. One provides for host citizen-investor arbitration ${ }^{5}$ and another provides for the litigation of such disputes by an institutional adjudicative body, such as an 'International Court of Civil Justice'. ${ }^{6}$ One purpose of this paper is to explore the legalities and practicalities of implementing these proposals. After com-

1 South Africa, 'Possible Reform of Investor-State Dispute Settlement (ISDS) - Submission from the Government of South Africa', A/CN.9/WG.III/WP.176, para. 52.

2 Take, for example, the counterclaim in Urbaser v. Argentina. As arbitral tribunals noted in its reasons, Argentina was claiming on behalf of its population that had (allegedly) been denied access to clean water, see, for example, ICSID, Urbaser S. A and Consorcio de Aguas Bilbao Bizkaia, Bilbao Biskaia Ur Partzuergoa v. The Argentine Republic, award of 8 December 2016, case no. ARB/07/26, para. 1211 ('The Tribunal therefore finds that Claimants' alleged failure to comply with the population's human right for water.' (emphasis added)).

3 See Borzu Sahabi, Noah Rubins and Don Wallace, Jr., Investor-State Arbitration (2nd edn, Oxford: Oxford University Press 2019), para. 2.64.

4 'Least-developed' state is preferred to 'least developed' state, which is the form used by UNCTAD, because 'least developed' is a compound expression when used as an adjective in respect of 'state', see Rosemary Roberts (chief ed.), New Hart's Rules (Oxford: Oxford University Press 2005), 53.

5 See Emmanuel T. Laryea, 'Making Investment Arbitration Work for All: Addressing the Deficits in Access to Remedy for Wronged Host State Citizens Through Investment Arbitration', Boston College Law Review 59 (2018), 2845-2875.

6 Maya Steinitz, The Case for an International Court of Civil Justice (New York: Oxford University Press 2019). 
pleting that exploration, the conclusion is that, despite the legal challenges and practical problems it faces, the international adjudication of host citizeninvestor disputes is possible. But it will hardly be effective in delivering justice on a broad scale. For that purpose, another element is needed, namely a mandatory insurance scheme for the benefit of host citizens. That this element is needed is the core thesis of this article.

Before getting to that core thesis, the necessity of the international adjudication of host citizen-investor disputes should be demonstrated. That demonstration is performed in section II. It takes the case of a farmer whose irrigation system is damaged by investor misconduct and shows the various problems that he is likely to face in seeking access to justice against the responsible investor. Section III. shifts the focus from the necessity of international adjudication of host citizen-investor disputes to their political feasibility. It asks: is it possible that states could get behind this idea? The factors that will likely influence the views of home states and host states on this question are identified here. Section IV. then turns to analysing the legal issues and practical problems of the international adjudication of host citizen-investor disputes. Section V. focuses on finding solutions for these issues and problems. One potential solution is a mandatory insurance scheme for the benefit of host citizens. Section V. puts forward a conception of how this scheme could function.

\section{The Normative Case for the International Adjudication of Host Citizen-Investor Disputes}

Consider this hypothetical case. ${ }^{7}$ Jack is a farmer in one of the world's least-developed states. A small stream flows through his farm. That stream is used for the irrigation of his crops. One day, its usual crystal-clear water turns green, thereby making it unusable for irrigation. The timing could not be worse. Jack's business has been suffering through a long drought - with no end in sight. Without adequate irrigation, his crops die, which translates into a total loss of Jack's annual salary. Through some investigations, Jack determines that mining operations further upstream are responsible for the pollution of the stream. He writes a letter to the mine owner - and gets no reply. He writes a second letter - again, no reply. In this situation, the default reaction is to advise Jack to take action against the mine owner in a

7 This scenario is inspired by the facts of Dominic Liswaniso Lungowe E Others v. Vedanta Resources Plc and Konkola Copper Mines Plc, [2016] EWHC 975. This case is further discussed in section III. below. 
court. But there are a number of factors that are likely to stop him from doing so.

\section{Practical Factors Inhibiting Access to Justice for Host Citizens}

The first factor is a basic lack of awareness on how to seek to access to justice in a court. According to data collected by the World Justice Programme, ${ }^{8}$ only 57.8 per cent (on average) of those persons surveyed in leastdeveloped states ${ }^{9}$ knew how to obtain advice for resolving the legal problems that they faced. Usually, the process of resolving these legal problems involved turning to a friend or family member. Jack has no such option. This is a toxic tort case. ${ }^{10}$ It is unlikely that a family member could help. A formal process in the courts will have to be started. A lawyer will be needed for this purpose. Interestingly, of the 57 per cent of respondents in least-developed states who knew how to obtain advice to resolve their legal problems, only about 10 per cent (on average) of those persons sought legal advice from a lawyer. ${ }^{11}$ This data suggests that a Jack-like claimant is unlikely to approach a lawyer. Other scholarship looking at access-to-justice problems in leastdeveloped states also comes to the same conclusion. ${ }^{12}$

It will be assumed that Jack knows a lawyer who can assist him. The lawyer only has bad news for Jack. This bad news consists of more than his fees, which

8 World Justice Project, Global Insights on Access to Justice: Findings from the World Justice Project General Population Poll in 101 Countries, 2019, available at $<$ https://worldjusticeproject. org/> accessed 11 August 2021.

9 Note that the following least-developed states were surveyed: Afghanistan, Angola, Benin, Burkina Faso, Congo-Kinshasa, Ethiopia, Ghana, Liberia, Madagascar, Malawi, Mali, Mauritania, Mozambique, Myanmar, Nepal, Niger, Senegal, Sierra Leone, Tanzania, Togo, Uganda, and Zimbabwe. Although Zimbabwe is not included in UNCTAD's official list of least-developed states (see <https://unctad.org/>), their non-inclusion is on account of the fact of their reluctance to be listed. They do, however, meet the criteria for inclusion, see United Nations Department of Economic and Social Affairs, Handbook on the Least Developed Country Category: Inclusion, Graduation and Special Support Measures (3rd edn, 2018) 12, available at $<$ https://www.un.org/> accessed 11 August 2021.

10 Some would contend that this is not a toxic tort case because the harm has not inflicted on Jack himself, but rather his property. The exact boundaries of a 'toxic tort', however, are not well defined, see Kyle D. Logue, 'Reparations as Redistribution', B. U. L. Rev. 84 (2004), 13191374 (1334).

11 Two outliers (Ethiopia and Tanzania) have been excluded from this calculation. There, respondents reported that they accessed help for their legal problems 38 per cent of the time, see World Justice Project (n. 8), 39, 100.

12 Jessica Vapnek, Peter Boaz and Helga Turku, 'Improving Access to Justice in Developing and Post-Conflict Countries: Practical Examples from the Field', Duke Forum for Law \& Social Change 8 (2016), 27-44 (33). 
Jack will have some difficulty paying. ${ }^{13}$ The lawyer also advises that because the courts are under-resourced, it will take years before the case can come to trial. ${ }^{14}$ Further, the lawyer says that there is good reason to question the integrity of the court officers..$^{15}$ There is a specific concern that the mine owner might seek to bribe its way to victory. Additionally, the lawyer is concerned that the judge might be biased against Jack because he belongs to an ethnic minority. This was an issue that came up in the case $A A A$ and others v. Unilever. This was a case brought before English courts by Kenyan claimants against a United Kingdom-based investor. ${ }^{16}$ There, the court recognised that one reason why it could accept jurisdiction was because, on account of their race, the claimants were unlikely to receive a fair trial in Kenya. ${ }^{17}$

\section{Legal Factors Inhibiting Access to Justice for Host Citizens}

Jack's lawyer has more bad news, but this time it is of a legal nature. While the courts could entertain his claim because the facts of the case occurred within their jurisdiction, ${ }^{18}$ the process of enforcement looks

13 See Vapnek, Boaz and Turku (n. 12), 41.

14 See generally The World Bank, Doing Business 2020 (number 32436, 2020). For an ordinary commercial contract, it took on average 717 days to enforce contractual performance in a least-developed state (Afghanistan: 1642 days; Angola: 1296 days; Bangladesh - Dhaka: 1442 days; Benin: 595 days; Bhutan: 225 days; Burkina Faso: 446 days; Burundi: 832 days; Cambodia: 590 days; Central African Republic: 525 days; Chad: 630 days; Comoros: 506 days; Democratic Republic of Congo: 610 days; Djibouti: 695 days; Eritrea: 490 days; Ethiopia: 530 days; The Gambia: 758 days; Guinea: 311 days; Guinea-Bissau: 1785 days; Haiti: 530 days; Kiribati: 660 days; Laos: 828 days; Lesotho: 615 days; Liberia: 1300 days; Madagascar: 811 days; Malawi: 522 days; Mali: 620 days; Mauritania: 370 days; Mozambique: 950 days; Myanmar: 1160 days; Niger: 380 days; Nepal: 910 days; Rwanda: 230 days; São Tomé and Príncipe: 1185 days; Senegal: 650 days; Sierra Leone: 515 days; Solomon Islands: 497 days; Somalia: 575 days; South Sudan: 228 days; Sudan: 810 days; Tanzania: 515 days; Timor-Leste: 1285 days; Togo: 488 days; Uganda: 490 days; Yemen: 645 days; and Zambia: 611 days). These figures are taken directly from the database 'Enforcing Contracts' available at: <https://www.doingbusiness.org/> accessed 11 August 2021.

15 See Ronald J. Daniels and Michael Trebilcock, 'The Political Economy of Rule of Law Reform in Developing Countries’, Mich. J. Int'l L. 26 (2004), 99-140 (120).

16 This case is a long-running saga that has progressed through English courts of English law. The claimants were ultimately unsuccessful in their attempts to argue that English courts enjoyed jurisdiction over their claims, see generally AAA \& Others v. Unilever PLC and Unilever Tea Kenya Limited, [2018] EWCA Civ 1532 (the claimants sought leave to appeal to the Supreme Court of the United Kingdom, but leave was denied).

17 AAA \& Others v. Unilever Plc and Unilever Tea Kenya Limited, [2017] EWHC 371 (QB), para. 168.

18 See Trevor C. Hartley, Civil Jurisdiction and Judgments in Europe: The Brussels I Regulation, the Lugano Convention, and the Hague Choice of Court Convention (Oxford: Oxford University Press 2017), para. 7.02. 
difficult. The lawyer understands that the mine owner is in financial dire straits. Any judgment debt against the mine owner would have a low ranking in any insolvency proceedings. ${ }^{19}$ One option to remedy this problem is to join the asset-rich parent company of the mine owner to the action, but the lawyer determines that the court is unlikely to have jurisdiction over this company and obtaining permission to serve this company with notice of the proceedings adds another layer of complexity to the matter. Additionally, the judgment debt against the parent company would have to be enforced in its home state, assuming that its sole asset in the jurisdiction is its shareholding in the soon-to-be liquidated mine owner. Because there is no treaty on recognition and enforcement between the host state and the home state, this enforcement will be legally difficult. ${ }^{20}$

As a final throw of the dice, the lawyer considers filing a claim against the parent company in its home state. But that path will be difficult to take. For although the courts will have jurisdiction over the parent company, ${ }^{21}$ the lawyer faces an uphill battle on the substantive front. The basic rule is that parent companies are not legally responsible for the conduct of their subsidiaries. In the future, this basic rule might be softened, particularly with respect to European companies. This is because various European states and the European Union have enacted or are considering the enactment of laws that would impose due diligence obligations on European companies with respect to, one, companies in their supply chains or, two, their subsidiaries. But these new laws might not prove to be the saving grace for claimants like Jack. Under French law, for example, these obligations only require that French companies prepare vigilance plans that identify risks and prevent severe impacts on human rights and fundamental freedoms, on the health and safety of persons, and on the environment'.22

19 Where exactly Jack's judgment debt would rank is a matter for determination under the insolvency laws of the host state. However, it should be expected that this (unsecured) debt would lie, at best, in a third category, behind administration fees relating to the insolvency proceedings and the claims of the secured creditors, see Horst Eidenmüller, 'Comparative Corporate Insolvency Law' in: Jeffrey N. Gordon and Wolf-Georg Ringe (eds), The Oxford Handbook of Corporate Law and Governance (Oxford: Oxford University Press 2016), 1023, para. 6.4.

20 This problem is particularly pronounced in the American legal system because the United States has not signed any treaties on recognition and enforcement of foreign judgments, see Yuliya Zeynalova, 'The Law on Recognition and Enforcement of Foreign Judgments: Is It Broken and How Do We Fix It', Berkeley J. Int. L. 31 (2013), 150-205 (151).

21 See, for example, Brussels I Regulation, Art. 4(1).

22 Elsa Savourey and Stéphane Brabant, 'The French Law on the Duty of Vigilance: Theoretical and Practical Challenges Since its Adoption', Business and Human Rights Journal 6 (2021), 141-152 (145). 
Under English law, ${ }^{23}$ claimants will have to show that, one, they suffered some form of legally recognised harm, two, there was a duty of care between them and the parent company, three, the parent company's supervision of its subsidiary was inadequate, and, four, the inadequacy of that supervision ultimately caused the harm. Mustering all of the proof needed for these purposes will, figuratively speaking, be a difficult hill to climb.

And even if a claimant can climb it, another more challenging climb lies ahead. Specifically, claimants like Jack will have to engage another lawyer in the parent company's jurisdiction, assuming that his original lawyer is not qualified to practise there. If the parent company is incorporated in a developed state, the legal fees will almost certainly be beyond the means of a farmer from a least-developed state. ${ }^{24}$ One potential solution to this problem are success fee arrangements between clients and lawyers. ${ }^{25}$ These arrangements come in various forms, ${ }^{26}$ but their main distinguishing factor is that the lawyer's remuneration is dependent on the success of the claim. ${ }^{27}$ They are particularly popular in Anglo-American jurisdictions ${ }^{28}$ and claimants in recent host citizen-investor disputes that have been litigated in English courts have made use of them. ${ }^{29}$ But contingency fee arrangements are not a silver bullet. All of the problems that afflict them cannot be detailed here, ${ }^{30}$ but one problem is worth special mention: the 'minimum

23 To claim under English law, Jack-like claimants would bring a negligence against the investor. The tort of negligence consists of four substantive elements: some form of legally recognised harm to the victim (investor); that harm must be caused by the tortfeasor (investor); a duty of care between the victim and the tortfeasor; and the causative conduct of the tortfeasor must fall below the standard of care owed to the victim, see Donal Nolan and John Davies, 'Torts and Equitable Wrongs' in: Andrew Burrows (ed.), English Private Law (3rd edn, Oxford: Oxford University Press 2013), paras 17.26-17.27 (note that Nolan and Davies list three elements, but later clarify that whatever harm a victim has suffered, it must legally recognised).

24 Deborah L. Rhode, Access to Justice (Oxford: Oxford University Press 2004), 32.

25 Laryea (n. 5), 2868.

26 See Richard Moorhead, 'An American Future? Contingency Fees, Claims Explosions and Evidence from Employment Tribunals', M. L. R. 73 (2010), $752-784$ (753-754).

27 Jonathan Law and Elizabeth A. Martin (eds), Oxford Dictionary of Law (7th edn, Oxford: Oxford University Press 2013), 534 (definition of 'success fee (contingency fee)').

28 See Adrian Yeo, 'Access to Justice: A Case for Contingency Fees in Singapore', Singapore Academy of Law Journal 16 (2004), 76-167 (76-78).

29 AAA \& Others (n. 17); Lungowe (n. 7) (for a discussion with the lawyer representing the claimants in this case and how they made use a success fee arrangement, see: <https:// www.dw.com/en/lungowe-v-vedanta-how-to-hold-multinationals-liable-for-harmful-activities/ a-52233779> accessed 11 August 2021); and Okpabi E Others v. Royal Dutch Shell Plc E Anor [2017] EWHC 89 (TCC). In all of these cases, the claimants were represented by the law firm 'Leigh Day', which is a law firm that generally acts on the basis of success fee arrangements with its clients.

30 For a comprehensive overview, see Lester Brickman, 'ABA Regulation of Contingency Fees: Money Talks, Ethics Walks’, Fordham L. Rev. 65 (1996), 247-336. 
claim value'. ${ }^{31}$ Unless the value of the claim exceeds a minimum amount, lawyers will not take them on because they will not be able to generate a profit from them. In the United States, for example, this amount is estimated to be USD $150,000 .{ }^{32}$

\section{Assessment of the Normative Case for International Adjudication of Host Citizen-Investor Disputes}

For Jack, it is apparent that access to justice cannot be secured in domestic courts, whether in the host state or the home state. This is not to say that all Jack-like claimants will suffer the same fate. In some cases, the generalisations and assumptions made in respect of this hypothetical case will not apply, but in many cases, it can be expected that they will apply. This is particularly true with respect to the generalisations and assumptions made vis-à-vis the domestic courts of investors' home states. The movement towards extending the liability of parent companies for the wrongful acts of those companies in their supply chains and their corporate group offers some promise, but the fear is that the cost of legal services in traditional home states will neuter this promise. The prospects for a Jack-like claimant to obtain justice look markedly better before the domestic courts of the host state. There, the legal difficulty of enforcing a judgment debt against the mine owner (local company controlled by the investor) only arose on account of its pending insolvency, which obviously was an exceptional circumstance. Still, there are practical problems: knowing where to turn to for legal assistance, legal costs, under-resourced courts, and integrity issues with court officers. The malfunctioning of domestic courts in the host state is the crux of the problem. ${ }^{33}$

\section{The Politics of Instituting the International Adjudi- cation of Host Citizen-Investor Disputes}

But the fact that there is this problem does not mean that states will rush to fix it by creating the possibility for the international adjudication of host citizen-investor disputes, most particularly if the specific fix involves institu-

31 Expression of 'minimum claim value' borrowed from Ugo Merlonea and Matteo Lupano, 'Third Party Funding: the Minimum Claim Value', European Journal of Operational Research (forthcoming).

32 Rhode (n. 24), 32.

33 See also Laryea (n. 5) 2855-2856. 
tional adjudication as opposed to arbitration. Creating the infrastructure for institutional international adjudication of host citizen-investor disputes would require investments in law reform. For those investments to be made, there will need to be more than an access-to-justice problem of a general nature there will also need to be political will. It should be noted that political will is not required for host citizen-investor arbitration because this mode of dispute settlement can be conducted by the parties without state participation.

This idea of international institutional adjudication of host citizen-investor disputes will be hardest to sell to traditional home states. The sales pitch will have to have more content than an appeal to the idea of corrective justice; ${ }^{34}$ in other words, traditional home states will not buy this idea if its only selling point is that it gives host-citizen claimants the chance to receive compensation for their injuries. Traditional home states will have to see that it is in their enlightened self-interest to back the idea of institutional international adjudication of host citizen-investor disputes. To reach this point of enlightenment, it should be emphasised that investor claims against states under investment treaties could be seen as more legitimate with the introduction of host citizen-initiated actions, ${ }^{35}$ and such increased legitimacy can only contribute to the long-term success of the regime. ${ }^{36}$ Another point worth emphasising is the potential cost-saving for investors. As most forcefully put by Steinitz, ${ }^{37}$ some investors might be in favour of international adjudication of their disputes with host citizens, as opposed to never-ending domestic litigation in multiple fora. The paradigm example is the Lago Agrio Oil Field Saga. ${ }^{38}$ This is a dispute ultimately between Ecuadorian citizens and Chevron. Litigation of this dispute began in 1993. After multiple cases before different American and Ecuadorian courts, and an investment-treaty arbitration, ${ }^{39}$ the dispute remains unresolved at the time of writing. ${ }^{40}$

34 Host citizen-investor disputes are essentially tort disputes and one of the traditional justifications for tort law has been the idea of corrective justice, see Jules Coleman, Scott Hershovitz and Gabriel Mendlow, 'Theories of the Common Law of Torts' in: Stanford Encyclopedia of Philosophy, para. 3.1, <https://plato.stanford.edu $>$.

35 See Gus Van Harten, The Trouble with Foreign Investor Protection (Oxford: Oxford University Press 2020), 67.

36 Laryea (n. 5), 2875.

37 See generally Steinitz (n. 6), 109.

38 Example taken from Steinitz (n. 6), 109.

39 For the main arbitral award of this investment-treaty arbitration, see PCA, Chevron Corporation and Texaco Petroleum Corporation v. Ecuador, case no. 2009-23, Second Partial Award on Track II (30 August 2018).

40 At the time writing, the last incident in this dispute was that the District Court of the Hague issued a judgment that upheld the arbitral award from the investment-treaty arbitration, see <https://www.forbes.com/sites/michaelkrauss/2020/09/22/international-tribunal-upholdschevrons-award-against-ecuador/> accessed 11 August 2021. 
Giving host citizens the possibility of claiming from investors before an international adjudicative institution is easier to sell to traditional host states. The simple reason is that most harm to host citizens caused by investor misconduct is likely to have a larger economic fall-out for them. ${ }^{41}$ For example, if an investor's employee is injured and rendered unable to work, then the human capital of this person is taken out of the national economy. Moreover, if he or she is not compensated by the investor and seeks health care services from public sources, then the host state has to effectively pay for the harm caused. He or she becomes an economic liability for the host state. Similarly, in cases involving environmental damage, there will be economic consequences. A case that illustrates this point is Lungowe v. Vedanta Resources. There, 1,826 Zambian nationals alleged that the investor's investment activities had polluted local waterways that they used for irrigation purposes. ${ }^{42}$ Owing to the pollution, they could not grow their agricultural produce, ${ }^{43}$ which in turn would have affected food production in Zambia. Because of the potential costs that the host state might have to shoulder if its citizens cannot bring international claims against investors, this idea should instinctively be attractive for some traditional host states.

\section{Critical Analysis of Proposals for the International Adjudication of Host Citizen-Investor Disputes}

On account of these factors, the running assumption is that the idea of international adjudication of host citizen-investor disputes will be attractive to at least some states. The incumbent task now is to build the procedural infrastructure for this idea.

For host citizen-investor arbitration, much of this task has already been completed. The principal piece of infrastructure needed is dedicated arbitral rules for these kinds of arbitrations. The Hague Rules on Business and Human Rights Arbitration (Hague Rules on BAHR Arbitration) could ideally serve this purpose. ${ }^{44}$ As the preamble of these arbitral rules make clear, they have been drafted with a view to apply to disputes between

41 For further details, see OECD, Equal Access to Justice for Inclusive Growth: Putting People at the Centre (Paris: OECD Publishing 2019), 35-36.

42 Lungowe (n. 7), para. 1.

43 Vedanta Resources PLC and another v. Lungowe and others, [2019] UKSC 20, para. 1.

44 Martin Jarrett, Sergio Puig and Steven Ratner, 'Investor Accountability: Indirect Actions, Direct Actions by States, and Direct Actions by Individuals', Journal of International Dispute Settlement, (forthcoming). 
individuals who have been adversely affected by the activities of business enterprises. ${ }^{45}$

For host citizen-investor litigation before an international adjudicative institution, Maya Steinitz has put forward an 'International Court for Civil Justice' and has drawn up detailed design plans. ${ }^{46}$. Such a court could hear host citizen-investor disputes, but, if it is ever going to be constructed, it is a long way off. ${ }^{47}$ Another emerging international institution might, however, serve as a venue for this purpose, namely the Multilateral Investment Court (MIC). ${ }^{48}$ Given that, at the time of writing, its design was being negotiated at UNCITRAL Working Group III, the idea of international adjudication of host citizen-investor disputes can be joined to that process. Additionally, and as noted in the introduction, South Africa has already called for the MIC to be designed to accommodate this form of adjudication. ${ }^{49}$ But if other states are ready to act on this call, they will need to focus their attention on some difficult legal issues, the first of which asks: who should be the 'investor' who should be sued?

\section{Legal Issue 1: Identity of the Investor}

In some cases, it will be readily apparent who the investor should be. If, for example, the investment is owned by a local company, which in turn is wholly owned by a foreign parent company, then that parent company will be the investor. But imagine if four foreign companies have equal ownership stakes in the local company - which of these four companies should be sued? Even more difficult, imagine a situation where none of these four companies' home states have ratified the treaty creating the MIC, meaning that the MIC has no jurisdictional competence over them. The MIC only has jurisdiction over one company that has an ownership stake in the investment. It is a pension fund with a 20 per cent shareholding in one of

45 The Hague Rules On Business and Human Rights Arbitration (December 2019), Preamble (para. 2(a)).

46 Steinitz (n. 6), chap. 5

47 See Steinitz (n. 6), 181

48 Describing the adjudicative proceedings before the MIC as 'litigation' is not an endorsement of the idea that these proceedings are not 'arbitration'. 'Litigation' is used in a general sense to mean adjudication before an institution, noting that MIC has a greater institutional character compared to traditional arbitration. For a discussion of the debate regarding whether the adjudicative proceedings before the MIC are arbitration, see Marc Bungenberg and August Reinisch, From Bilateral Arbitral Tribunals and Investment Courts to a Multilateral Investment Court (2nd edn, Heidelberg: Springer 2020), paras 495-536.

49 See n. 1. 
these four companies, thereby giving it an indirect stake of 5 per cent in the investment. Should a host citizen have the possibility of suing this pension fund before the MIC?

There are two possible approaches to these two questions on the investor status of these four companies (assuming that they could all be sued before the MIC) and the pension fund (assuming that none of the four companies could be sued before the MIC, but the pension fund could be). The first approach is grounded in the idea of 'taking the burdens with the benefits'; ${ }^{\circ}$ specifically, if an investor has the benefit of investor status as regards investor-state disputes, then it should also accept the burden of investor status as regards host citizen-investor disputes. If this becomes the rule regarding the identity of the investor who may be sued, then each of the four companies with 25 per cent shareholdings could be sued and, under most definitions of 'investor' found in investment treaties, the pension fund could be sued as well. ${ }^{51}$ Some of these four companies and, most particularly, the pension fund will protest. The foundation of their protest will be that they exercised no control over the day-to-day operations of the local company, presumably citing that principle that a person should not bear responsibility for an injury unless he or she had control over the conduct that caused it. ${ }^{52}$ This is the second approach: that an investor must have control over the investment activities. An example of this approach was played out in Lungowe v. Vedanta Resources. The facts of this case were detailed towards the end of section III. In resisting the host citizens' claim, a key argument for the investor was that it did not actively manage its local subsidiary's activities. The Supreme Court of the United Kingdom confirmed that that active management was a pre-requisite to liability for a parent company (investor). ${ }^{53}$

50 Sometimes this principle is expressed with the Latin maxim 'qui sentit commodum sentire debet et onus', see Christine J. Davis, 'The Principle of Benefit and Burden', CLJ 57 (1998), 522-553.

51 Lukas Vanhonnaeker, Shareholders' Claims for Reflective Loss in International Investment Law (Cambridge: Cambridge University Press 2020), 103.

52 See William Lucy, Philosophy of Private Law (Oxford: Oxford University Press 2007), 144.

53 Vedanta Resources (n. 43), para. 49. The court did not ultimately have to decide whether the parent company did actively manage the local company. The case concerned the jurisdiction of the English courts over the claimants' claim. English courts could only exercise jurisdiction if there was a 'triable issue' at hand; in other words, the claimants needed to demonstrate that they had a case that had a reasonable prospect of success. Part of demonstrating that their claims had such prospects depended on whether there was a bare amount of evidence showing that the parent company actively managed the local company, which the claimants were ultimately able to demonstrate, see Vedanta Resources (n. 43), para. 61. 
The 'ownership approach' and the 'control approach' are both legally feasible, but some factors lean in favour of the control approach. First, the 'taking the burdens with the benefits' principle is not as strong as it might appear. ${ }^{54}$ The situation between passive investors with minority ownership stakes and host citizens is different compared to the situation between host states and these investors (and their investments). Their ownership stakes (investments) are vulnerable to deprivation or devaluation on account of state conduct, whereas host citizens cannot be injured by passive investors. A second factor is insurance. As detailed in section V.2. below, it is proposed that a mandatory insurance scheme for host citizen-investor disputes should be set up. What makes this scheme mandatory is that if an investor wishes to access the MIC, for example, it needs an insurance policy for the benefit of host citizens. Placing this effective obligation on controlling investors makes sense because of their more active role in the management of the investment, but it would be an overreach in respect of passive investors. The third factor is the most powerful. It concerns the nature of investors' liability: should it be several or joint and several?55 For the efficacy of the regime, there has to be a strong preference for joint and several liability. ${ }^{56}$ To illustrate this point, take a scenario where one investor owns a shareholding of 60 per cent in the local company and four other investors each own 10 per cent. The MIC only has jurisdiction over the majority shareholder because its home state has ratified the treaty creating the MIC, while the home states of the other investors have not. If this majority shareholder's liability is limited to 60 per cent of the total value of the host citizen's loss, then few host citizens will make the necessary efforts to file a claim against it. But suppose that this majority shareholder is joint and severally liable - this attitude immediately changes. Considering that it has a controlling stake in the investment, this

54 The 'taking the burden with the benefit' principle is well known in English law. In Lissenden v. C. A. V. Bosch, Lord Wright issued this warning about this principle and others like it: 'general formulae are found in experience often to distract the Court's mind from the actual exigencies of the case, and to induce the Court to quote them as offering a ready made solution. But it is not safe to act upon them unless and to the extent that they have received definition and limitation from judicial determination.' See Lissenden v. C. A. V. Bosch, Ltd. [1940] A. C. $412,435$.

55 A third option is 'joint liability'. It has been excluded, however, because the distinction between it and joint and several liability is usually only a procedural one. Specifically, if liability among a group of persons is joint, then all of them have to be sued in an action against them in respect of their joint liability. But if liability is joint and several, then only one of these persons needs to be sued.

56 One of the traditional justifications for joint and several liability is that a joint tortfeasor had moral culpability because of his or her actions towards the occurrence of the harm, see Larry Pressler and Kevin V. Schieffer, 'Joint and Several Liability: A Case for Reform', Denver Law Review 64 (1987-1988), 651-684 (669). 
imposition of joint and several liability is easy to justify, but this is not the case with respect to passive investors with minority ownership stakes. Imagine, for example, that the MIC only had jurisdiction over one company with a 10 per cent shareholding - it would be surprising if it had to accept liability for the other companies in the consortium.

Naturally, majority shareholders will feel aggrieved that they have to assume liability for the passive investors. ${ }^{57}$ To counter this feeling, at least under domestic law, a majority shareholder would file a contribution action against the other investors to obtain reimbursement for the costs paid on their behalf, 58 but, if the MIC serves as the adjudicative forum for host citizen-investor disputes, it is doubtful whether such a contribution action could be filed there. The problem here is that the MIC would need jurisdictional competence over the other passive investors, which it might not have. This is not particularly problematic for joint-and-severally-liable majority shareholders, however. Through shareholder agreements, the matter can be regulated between the investors (shareholders) themselves; for example, in this agreement, the other shareholders can agree to indemnify the majority shareholder if it is sued before the MIC by a host citizen.

Another issue that has to be addressed is the meaning of 'controlling investor'. Some rebuttable presumptions can be useful for this purpose. A common one is if a company or corporate group has an ownership stake of more than 50 per cent in the investment, then it is a controlling investor. ${ }^{59}$ Formulating a presumption with respect to consortiums in which the partners hold equal shares in the investment is more difficult; for example, where each partner holds 25 per cent. It is submitted that each partner should be classified as a 'controlling investor'. For this purpose, cues are taken from domestic law where, generally speaking, partners are jointly and severally liable for the others' liabilities. ${ }^{60}$

57 Although this is not the ground of protest. For an overview of the protests that investors are likely to level at joint and several liability, see generally Richard W. Wright, 'The Logic and Fairness of Joint and Several Liability', Mem. St. U. L. Rev. 45 (1992), 45-84.

58 Christian Witting, 'Joint Liability' in: Peter Cane and Joanne Conaghan (eds), The New Oxford Companion to Law (Oxford: Oxford University Press 2008), 646.

59 See, for example, OECD, 'Control of a Corporation' (Glossary of Statistical Terms, 23 April 2013) <https://stats.oecd.org/> accessed on 27 May 2021.

60 For English law, see Partnership Act 1890, s. 9 (the rule contained in this section also applies to limited partnerships, see John Armour, 'Companies and Other Associations' in: Burrows (n. 23), 165 (para. 3.114)). For French law, Code de Commerce (Book II), Art. L221-1 (for general partnerships) and Art. L222-1 (for limited partnerships). For German law, see HGB, s. 128 (see Martin Schulz and Oliver Wasmeier, The Law of Business Organizations: A Concise Overview of German Corporate Law (Heidelberg: Springer 2012), 28). 


\section{Legal Issue 2: Applicable Substantive Law}

The next legal issue concerns the applicable substantive law of host citizen-investor disputes. In international arbitration, making the determination is simple. Under the Hague Rules on BAHR Arbitration, ${ }^{61}$ for example, the parties select this law, and, if they fail to make a selection, then the arbitral tribunal may apply the law which it thinks is most appropriate. This popular two-step formula might also be used by adjudicators in respect of host citizen-investor disputes before the MIC. There are, however, hidden problems with this mode of determining the applicable substantive law. First, for most host citizen-investor disputes, it is suspected that the first rule allowing for party-selection will be redundant. The reason is on account of the nature of host citizen-investor disputes, which will usually be tortious in nature. The parties will seldom select the applicable substantive law prior to their dispute. ${ }^{62}$ Coupled with the fact that the parties are very unlikely to come to a mutually agreeable applicable substantive law after the dispute arises, ${ }^{63}$ the result is the redundancy of the first rule. The apparent saving grace is the second rule under which the adjudicators make the selection. When an arbitral tribunal under the Hague Rules on BAHR Arbitration or adjudicators of the MIC apply this rule, the chances are that they will land on the domestic law of the host state as the most appropriate applicable substantive law, particularly considering that the facts of the disputes will have occurred there. But the use of this body of law in the international adjudication of host citizen-investor disputes raises some red flags.

The first red flag concerns the identity of the presiding arbitrators or adjudicators. Unless they are judges or high-ranking jurists from the host state, then they will need expert evidence on the content of domestic law in the host state. What the need for expert evidence ultimately equates to is time and money. Additionally, questions will be asked about the quality of justice delivered on the basis of (presumably) days or, at best, weeks studying this expert evidence. The way-out is to appoint judges or high-ranking jurists from the host state to act as adjudicators, but then the international adjudication of host citizeninvestor disputes starts to look like internationally supported domestic adjudi-

61 The Hague Rules on Business and Human Rights Arbitration (2019), Article 46.

62 For methods on how tortfeasors have sought to overcome this practical problem via arbitration agreements in contracts, see Elizabeth G. Thornburg, 'Contracting with Tortfeasors: Mandatory Arbitration Clauses and Personal Injury Claims', Law \& Contemp. Probs. 67 (2004), 253-278 (254-256).

63 See Gary Born, International Arbitration: Law and Practice (2nd edn, Alphen aan den Rijn: Wolters Kluwer 2016), 34 (noting that getting to any agreement on arbitration after a dispute has arisen is often very difficult). 
cation. Considering that there are already domestic courts in place for host citizen-investor disputes, the money that would be spent on this internationally supported domestic adjudication might simply be better used by investing into the productivity (and rule-of-law credentials) of these domestic courts.

This point is a good lead-in to the second red flag about applying domestic law, specifically the integrity of the legal order from which that domestic law originates. The problem here is that if international adjudicative bodies are applying domestic law outside the supervision of superior courts, then the judges that sit on those courts could react adversely. ${ }^{64}$ The case in point is Slovakia v. Achmea before the European Court of Justice (ECJ). ${ }^{65}$ In that case, the ECJ effectively issued an interdiction order on intra-European Union investment-treaty arbitrations ${ }^{66}$ because arbitral tribunals necessarily had to apply European Union law in them, ${ }^{67}$ which is a task that the ECJ ruled that it had to have ultimate supervision over. ${ }^{68}$ As arbitral tribunals for investment-treaty arbitrations were not part of the court hierarchy that the ECJ sat at the top of, ${ }^{69}$ and they could not be included in it, ${ }^{70}$ the result was that the ECJ lacked supervision over them.

The main criticism of this decision is that it is doctrinally incompatible with the position adopted in respect of commercial arbitrations, where arbitral tribunals apply European Union law outside the authority of the ECJ, yet do so without any objection from its end. The ECJ in Slovakia v. Achmea acknowledged this criticism, ${ }^{71}$ but explained that investment-treaty arbitration was different because states, by submitting to arbitration in investment treaties, take away adjudicative power from their domestic courts by setting up a parallel system of adjudication. ${ }^{72}$ And the same process would most likely have to occur in respect of the international adjudication of host citizen-investor disputes, whether the adjudication takes the form of arbitration or litigation before the MIC. The qualifier 'most likely' is added because, in some cases, the host citizen and the investor will choose to conduct

64 In his analysis, Laryea also suspects that Australian superior courts would be likely to rule that international adjudicative proceedings based on Australian law are unconstitutional, see Laryea (n. 5), 2873.

65 ECJ, Slovak Republic v. Achmea BV (Slovakia v. Achmea), judgment of 6 March 2018, case no. C-284/16, ECLI:EU:C:2018:158.

66 Burkhard Hess, 'The Fate of Investment Dispute Resolution after the Achmea Decision of the European Court of Justice', MPILux Research Paper 3 (2018), 9.

67 Slovakia v. Achmea (n. 65), para. 42.

68 Slovakia v. Achmea (n. 65), para. 43.

69 Slovakia v. Achmea (n. 65), para. 49.

70 Slovakia v. Achmea (n. 65), para. 58.

71 Slovakia v. Achmea (n. 65), para. 54.

72 Slovakia v. Achmea (n. 65), para. 55. 
arbitration on their own accord, meaning that state intervention will not be necessary for the participation of the investor. But these cases will presumably be rare. Investors will not voluntarily sign up for host citizens to sue them in arbitration or before the MIC. States will have to step in to, in some way, compel investors to arbitrate. This step raises a legal issue regarding the legality of the method that compels investors to submit, an issue which is addressed below. ${ }^{73}$ This legal issue can be put to one side for the time being. For present purposes, what is important is that, with this step, states will be taking away adjudicative power from their own courts over disputes that they would ordinarily hear.

It will be noted that the proof sitting behind this second red flag is one decision from one court. But these numbers do not accurately communicate the significance of this decision, most particularly in respect of the MIC. The ECJ is the ultimate adjudicative authority over the main proponent of the MIC, namely the European Commission. ${ }^{74}$ Because of this, the idea that the adjudicators of the MIC must not adjudicate on matters of domestic law is finding its way into the first drafts of the treaty that would create the MIC. ${ }^{75}$ In those drafts, domestic law is not given a role as a body of law that would resolve legal issues in a dispute - international law has a monopoly over that role. Rather, the first drafts only see domestic law as becoming relevant as a matter of fact. For it to play that role, it could not be used as the applicable substantive law in host citizen-investor disputes. ${ }^{76}$

To avoid these red flags, the solution is to apply international law. But what body of rules in international law could serve that purpose? There are some candidates: the Principles of European Tort $\mathrm{Law}^{77}$ and the United Nations Guiding Principles on Business and Human Rights. ${ }^{78}$ But looking past some specific difficulties that might inhibit the application of these bodies of rules, ${ }^{79}$ there is a fundamental problem that affects both of them:

73 See section IV.3. below.

74 European Commission, 'The Multilateral Investment Court Project' (News Archive, 21 January 2016) <http://trade.ec.europa.eu> accessed 11 August 2021.

75 UNCITRAL Secretariat, 'Appellate Mechanism and Enforcement Issues' (12 November 2020), A/CN.9/WG.III/WP.202, para. 59.

76 See Jarrod Hepburn, 'Domestic Law in International Adjudication' in: Anne Peters (ed.), MPEPIL (online edn, Oxford: Oxford University Press 2018), para. 11.

77 See <http://www.egtl.org/> accessed 11 August 2021.

78 See <https://www.ohchr.org/>accessed 11 August 2021.

79 Particularly in respect of the UN Guiding Principles on Business and Human Rights, they were not drafted with the intention of being 'hard rules' to apply in actual cases, see generally Stéphanie Lagoutte, 'The UN Guiding Principles on Business and Human Rights: A Confusing “Smart Mix" of Soft and Hard International Human Rights Law' in: Stéphanie Lagoutte, Thomas Gammeltoft-Hansen and John Cerone (eds), Tracing the Roles of Soft Law in Human Rights (Oxford: Oxford University Press 2016), 235. 
they live in jurisprudential poverty. Although they have been put together by some renowned names, ${ }^{80}$ there is a lack of jurisprudence on their application, remembering that they have not been applied in adjudication and the amount of scholarship explaining their application is limited. This poverty should be compared with the rich jurisprudence on the rules of civil liability in domestic law. In most jurisdictions, these rules are supported by scholarship going back decades and have been applied in innumerable cases. This does not mean that a rich body of jurisprudence on international civil liability could not be constructed, but this process of construction would take time. If that investment in time were made, however, a body of jurisprudence could be tailored to fit the nuances of host citizen-investor disputes, which counts as the main advantage of using international law as their applicable substantive law.

\section{Legal Issue 3: State-Compelled Consent of Investor}

A third issue concerns the legal validity of investors' consent to international adjudication with host citizens when such 'consent' is compelled by its home state.

Starting with host citizen-investor arbitration, the presumption is that many investors will be unwilling to sign up. The reason for this reluctance is that signing-up legally means that they will open up a liability front with host citizens where none previously existed. Unless this new liability front closes another (less favourable) liability front before domestic courts, ${ }^{81}$ there is no apparent reason why it should be opened. One solution to this problem is for home states to step in by consenting on behalf of their investors. ${ }^{82}$ For example, the states party to an investment treaty could agree

80 The Principles of European Tort Law were put together by the European Group on Tort Law, whose members are listed here: <http://www.egtl.org/> accessed 11 August 2021. As regards the UN Guiding Principles on Business and Human Rights, the principal architect was Prof. John Ruggie. For an overview of the drafting process, see Nicola Jägers, 'UN Guiding Principles on Business and Human Rights: Making Headway Towards Real Corporate Accountability?', NQHR 29 (2011), 159.

81 Legally, an arbitration agreement excludes recourse to courts for the determination of disputes that fall within its scope, that is not in question, see Gary Born, International Commercial Arbitration (3rd edn, Alphen aan den Rijn: Kluwer Law International 2021), para. 8.03. The question is whether arbitration is a better alternative to litigation for the investor. If the investor understands that the host citizen faces a bevy of problems as regards his or her access to local courts, then arbitration might not be the better alternative.

82 For a detailed examination of how this process might work, see Jose Daniel Amado Lima, Jackson Shaw Kern and Martin Doe Rodriguez, Arbitrating the Conduct of International Investors (Cambridge: Cambridge University Press 2017), 87-93. 
that their investors consent to arbitration between themselves and host citizens. ${ }^{83}$

But there would have to be serious doubt about the validity of this offer of arbitration to host citizens 'by investors'. International arbitration is consensual in nature - the parties who agree to arbitration are the only ones who participate in it. ${ }^{84}$ This general rule is subject to a number of exceptions whereby third parties can become participants in arbitration, but none could be activated in a situation where the state consents on behalf of its investors. ${ }^{85}$ A new exception would have to be created. To create that exception, consentgiving states could argue that they have complete control over their subjects at the international level, a principle that McNair described as follows: ${ }^{86}$

'It appears to be a governing rule or assumption, for which it is difficult to find specific authority, that international law regards a State as being invested for international purposes with complete power vis-à-vis another contracting party to alienate and otherwise affect the rights of its nationals, both proprietary and personal, to surrender their property and claims, and to impose liabilities upon them.'

On account of this control, they could theoretically, in a treaty, make an offer of arbitration on behalf of their investors to host citizens. Accepting that this statement is still an accurate representation of the jurisprudence in international law,, 87 it is considered that it would not find favour with domestic courts, remembering that they would be the enforcers of any arbitral award from a host citizen-investor arbitration. ${ }^{88}$ This likely lack of respect is on account of oxymoronic nature of 'state-compelled arbitration'. The core of arbitral tribunals' adjudicative power is the parties' consent, which would necessarily be absent if home states compel their investors to arbitrate. ${ }^{89}$ This lack of consent means that the arbitral proceedings could not be described as arbitration, with the result that any decision coming from them could not be called an arbitral award. State-compelled arbitration is really court-like litiga-

83 For other options on how to procure consent, see Laryea (n. 5), 2869-2875.

84 Stavros L. Brekoulakis, Third Parties in International Commercial Arbitration (Oxford: Oxford University Press 2010), para. 1.20.

85 For a comprehensive list of the exceptions based on the apparent authority of one party to bind another party to an arbitration agreement, see Brekoulakis (n. 84), paras 2.112-2.142.

86 Lord McNair, The Law of Treaties (Oxford: Oxford University Press 1986), 324.

87 For a discussion of this issue, see Anne Peters, Beyond Human Rights: The Legal Status of the Individual in International Law (Oxford: Oxford University Press 2016), 72-75.

88 Nigel Blackaby, Constantine Partasides, Alan Redfern and Martin Hunter, Redfern and Hunter on International Arbitration (6th edn, Oxford: Oxford University Press 2015), para. 11.02 .

89 Andrea Marco Steingruber, Consent in International Arbitration (Oxford: Oxford University Press 2012), para. 2.01. 
tion for that person who is the subject of the compulsion. Using its sovereign power, a state directs that the subjects of its order submit to the authority of a certain adjudicative body. ${ }^{90}$

This is not the end of the idea of international adjudication of host citizeninvestor disputes - it simply means that state-compelled arbitration will be presumed to be legally difficult. The better option is for states to admit that they are forcing their investors to submit to court-like international litigation with host citizens. For this purpose, they can draft provisions that, one, direct their investors to participate in this litigation and, two, create an enforcement regime among the contracting states to the effect that their courts must treat judgments as judgments of their own. ${ }^{91}$ The limiting factor with this plan, however, is that only the courts of the contracting states to this treaty could enforce the judgments; in other words, if these provisions are included in a bilateral investment treaty, then only the courts of two contracting states could enforce the judgments. Considering that most investors will have most of their assets in their home states, this limiting factor should not usually translate into enforcement difficulties. But the enforcement regime would be stronger if it were found in a multilateral treaty. The leading candidate for this purpose is the treaty for creating the MIC. An enforcement mechanism for judgments from host citizen-investor disputes would have to be added to it. Scholarship that has been produced on the MIC has already concluded that this treaty should create a special enforcement regime for the enforcement of judgments from investor-state disputes, considering that such judgments will almost certainly not be classified as International Centre for Settlement of Investment Disputes (ICSID) awards nor arbitral awards as understood under the New York Convention. ${ }^{92}$

Accordingly, the most suitable forum for the international adjudication of host citizen-investor disputes is the MIC. The investor that is sued there is likely to argue that it lacks adjudicative power over it because the investor has not consented to its jurisdiction, remembering that the validity of international adjudication derives from the parties' consent. This argument is bound to fail. And its failure is not only explained by the scholarship of McNair, cited above, in which he opines that states have complete power over their subjects in international law, presumably meaning that they can subject them to the jurisdiction of an international court, such as the MIC. Another reason for its inevitable failure is the well-established jurisprudence

90 Hartley (n. 18), para. 7.03.

91 Following the formula designed by the ICSID Convention for the enforcement of its awards, see ICSID Convention, Art. 54(1).

92 Bungenberg and Reinisch (n. 48), para. 541. 
from international criminal law on the adjudicative power of the International Criminal Court over defendants, who, like investors in their capacity as respondents in host citizen-investor disputes, are compelled by states to act in this role. Numerous defendants who have been prosecuted at the International Criminal Court, and other ad hoc international law-based criminal courts, have tried to argue that they cannot stand trial because they have not consented to the relevant court's jurisdiction - none has met with any success. ${ }^{93}$

Looking at the example of the International Criminal Court, it is apparent that states can carve out some of the adjudicative power that ordinarily resides with their domestic courts and give it to an international court. For this reason, a MIC with a chamber for host citizen-investor disputes should be legally valid at international law. But this is not the end of the story. The other part of the story is the principle of deference towards domestic courts. ${ }^{94}$ This principle is particularly apparent in the treaty creating the International Criminal Court because this court should only exercise jurisdiction when domestic courts are incapable of acting. ${ }^{95}$ This principle is also familiar to jurists of international investment law because, under its predecessor, the law of diplomatic protection, domestic remedies had to be exhausted before international adjudication could be initiated. ${ }^{96}$ This principle, however, is not a hard rule of international law. ${ }^{97}$ The best proof of this is traditional investor-state arbitration, one of the defining features of which is that the investor does not have to exhaust local remedies in the host state. $^{98}$ Those charged with drafting the treaty provisions that would create the possibility of international adjudication of host citizen-investor disputes before the MIC would not need to include any requirement to exhaust local remedies.

93 Since the Nuremberg Trials, the principle of immunity of state officials was done away with in respect of international crimes, thereby pathing the way for the exercise of adjudicative power by international criminal tribunals over individuals, see Elies van Sliedregt, Individual Criminal Responsibility in International Law (Oxford: Oxford University Press 2012), 4.

94 The same principle is also in operation in respect of the doctrine on exhaustion of local remedies, see James R. Crawford and Thomas D. Grant, 'Exhaustion of Local Remedies' in: Peters (n. 76), para. 7.

95 Rome Statute of the International Criminal Court of 17 July 1998, 2187 United Nations Treaty Series 90, Article 1 ('An international criminal court [...] shall be complementary to national criminal jurisdictions').

96 John Dugard, 'Diplomatic Protection' in: Peters (n. 76), para. 53.

97 See John Dugard, 'Diplomatic Protection' in: James Crawford, Alain Pellet, Simon Olleson and Kate Parlett (eds), The Law of International Responsibility (Oxford: Oxford University Press 2010), 1062.

98 Rudolf Dolzer and Christoph Schreuer, Principles of International Investment Law (2nd edn, Oxford: Oxford University Press 2012), 264. 


\section{Impracticalities of the International Adjudication of Host Citizen-Investor Disputes}

And they should dispense with this requirement. It would be paradoxical to conclude that access-to-justice problems in domestic courts means that host citizens should have the option to pursue international justice against investors, but only after they have exhausted local remedies in those same courts. Moreover, fulfilling this requirement would place another financial strain on host citizens. But even if host citizens are not made to exhaust local remedies, they will still face financial difficulties in bringing a claim against an investor. These are the impracticalities of the international adjudication of host citizen-investor disputes.

The most apparent of these financial difficulties is the general expense of international adjudication for the host citizen. If the MIC follows the example set by other international adjudicative bodies, such as the International Court of Justice and the International Tribunal for the Law of the Sea, then the host citizen will have a free choice regarding who represents him or her. ${ }^{99} \mathrm{But}$ if the host citizen wishes to engage a lawyer who has experience in international adjudication, his or her options will usually be limited to lawyers who practise in highly developed states, such as Australia, Canada, France, Switzerland, United Kingdom, and United States. ${ }^{100}$ The cost of legal services in these jurisdictions will invariably be higher than the cost in developing states. This is not to say that lawyers from outside highly developed markets for legal services cannot litigate before international adjudicative bodies, ${ }^{101}$ but merely points out that the most experience will be found in these markets.

Another financial factor is the nature of international adjudication. Unlike domestic courts, the jurisdiction of international adjudicative bodies is in question in most cases. ISDS provides a good example of this phenomenon. In any treaty-based arbitration of an investor-state dispute, there will be questions about whether the claimant is an 'investor' or whether it owns an 'investment' or, in many cases, both. ${ }^{102}$ This situation will not necessarily

99 See Eran Sthoeger and Michael Wood, 'The International Bar' in: Cesare P. R. Romano, Karen J. Alter and Yuval Shany (eds), The Oxford Handbook of International Adjudication (Oxford: Oxford University Press 2013), 641.

100 See Sthoeger and Wood (n. 99), 641. As regards investment arbitration more specifically, see Malcolm Langford, Daniel Behn and Runar Hilleren Lie, 'The Revolving Door in International Investment Arbitration', JIEL 20 (2017), 301-332 (316).

101 See further James Gathii, 'The Promise of International Law: A Third World View', AJIL 114 (2021), 165-187 (167).

102 See Dolzer and Schreuer (n. 98), chap. 3 (chapter on jurisdictional requirements that focuses on the requirements of 'investor' and 'investment'). 
be replicated with respect to the international adjudication of host citizeninvestor disputes. Indeed, if an investor did argue that it was not an 'investor' or it did not own an 'investment', those arguments might be turned against it in an international adjudication of an investor-state dispute, ${ }^{103}$ thereby meaning that investors might refrain from making these arguments. But there is another jurisdictional requirement that they can raise without this risk. As argued in section IV.1. above, it is considered that only 'controlling investors' should be liable to be sued by host citizens in international adjudication. If the question of whether an investor is a 'controlling investor' becomes part of the equation for determining jurisdiction, ${ }^{104}$ which it should as part of the jurisdictional requirement on 'personal jurisdiction', 105 then investors will habitually challenge jurisdiction on this ground. This legal hurdle will not be the last hurdle in front of host citizens. Another potential hurdle is the enforcement of the judgment against the investor. Assuming that the MIC will not have an apparatus for enforcing its judgments, ${ }^{106}$ the result will be that the host citizen will have to seek enforcement in domestic courts, in the event that the investor refuses to pay the compensation award. It would be hoped that this enforcement process would not involve more than summary proceedings, ${ }^{107}$ meaning that the costs of these proceedings would not compare to costs of comprehensively litigating of the dispute before the enforcing court. But, again, the point remains that if the host citizen has to enforce in domestic courts, this practically equates to (some) more legal costs.

103 The matter hangs on whether the doctrine of issue estoppel is recognised and applied by the MIC. For an overview of the status of this doctrine in investment-treaty arbitration, see Gavan Griffith QC and Isabella Seif, 'Work in Progress: Res Judicata and Issue Estoppel in Investment Arbitration' in: Michael J. Moser and Neil Kaplan (eds), Jurisdiction, Admissibility and Choice of Law in International Arbitration: Liber Amicorum Michael Pryles (Alphen aan den Rijn: Wolters Kluwer 2018), para. 8.03.

104 If it was not relevant to jurisdiction, then this requirement would become part of the merits. Specifically, it would be an element in the cause of action that the claimant has to prove to obtain the remedy that it seeks.

105 Because it is part of the identity of the investor, then it should fall under the umbrella of 'personal jurisdiction', see Yuval Shany, 'Jurisdiction and Admissibility' in: Romano, Alter and Shany (n. 99), para. 2.1.1.

106 This is one of the general weaknesses of international adjudication, see Alexandra Huneeus, 'Compliance with Judgments and Decisions' in: Romano, Alter and Shany (n. 99) 437.

107 Interestingly, when the New York Convention was being drafted, one of the drafts put forward of Article 3 provided that foreign arbitral awards should be enforced via summary proceedings, although this proposal was ultimately displaced by the current rule that enforcement procedures should be the same for foreign and local arbitral awards, see Andreas Börner, 'Article III' in: Herbert Kronke and others (eds), Recognition and Enforcement of Foreign Arbitral Awards (Oxford: Oxford University Press 2010), 118. 
As previously mentioned, one way around the problem of costs for host citizens is with success fee arrangements. Some of the problems with success fee arrangements have been noted in section II.3. above. And specifically with respect to the MIC, there is another lurking problem with success fee arrangements. At the negotiations at UNCITRAL Working Group III for the reform of ISDS, numerous objections have been raised about third-party funding. ${ }^{108}$ Some states have advocated for ${ }^{109}$ or have signalled an openness to ${ }^{110}$ a prohibition on third-party funding in the reformed version of ISDS. ${ }^{111}$ Naturally, if the MIC becomes that reformed version of ISDS and the prohibition is enacted, then third-party funding will be banned in cases before the MIC. If success fee arrangements amount to 'third-party funding', which they do according to some definitions, then host citizens will not be able to use them. But this is a big 'if'. Only with a broad definition of 'thirdparty funding' could success fee arrangements fall within it. ${ }^{112}$ Moreover, states that have been concerned with third-party funding in ISDS have been concerned about how investors use it to fund their claims against states. An exception might be admitted in the case of host-citizen claims against investors. ${ }^{113}$ Finally, and most importantly, the consensus view that is emerging among states on the issue of third-party funding is that it should be regulated, not prohibited. ${ }^{114}$

108 UNCITRAL Secretariat, 'Third-Party Funding - Possible Solutions' (2 August 2019), A/CN.9/WG.III/WP.172, para. 3.

109 South Africa (n. 1), para. 66.

110 Morocco, 'Submission from the Government of Morocco' (4 March 2019), A/CN.9/ WG.III/WP.161, para. 30.

111 See further UNCITRAL Secretariat (n. 108), paras 15-16.

112 Stavros L. Brekoulakis and Catherine Rogers, 'Third-Party Financing in ISDS: A Framework for Understanding Practice and Policy' (October 2019) Academic Forum on ISDS Concept Paper 2019/13, 6 <https://www.jus.uio.no/pluricourts/english/projects/leginvest/ academic-forum/papers/papers/13-rogers-brekoulakis-tpf-isds-af-13-2019-version-2.pdf> accessed on 11 August 2021.

113 For example, in a submission paper submitted by the Netherlands, Peru, and Thailand on the problem of the financing of legal costs for host states in investment-treaty arbitration, it was suggested that third-party funding was one potential solution, see The Netherlands, Peru, and Thailand, 'Submission from the Governments of the Netherlands, Peru and Thailand' (19 March 2020), A/CN.9/WG.III/WP.196, 4.

114 Turkey, 'Submission from the Government of Turkey' (11 July 2019), A/CN.9/WG.III/ WP.174, 3; China, 'Submission from the Government of China' (19 July 2019), A/CN.9/ WG.III/WP.177, 5; South Korea, 'Submission from the Republic of Korea' (31 July 2019), A/ CN.9/WG.III/WP.179, 4; Kazakhstan, 'Submission from the Government of Kazakhstan' (23 October 2019), A/CN.9/WG.III/WP.187, 2; Chile, Israel, and Japan, 'Submission from the Governments of Chile, Israel and Japan' (15 March 2019), A/CN.9/WG.III/WP.163, 7; Costa Rica, 'Submission from the Government of Costa Rica' (22 March 2019), A/CN.9/WG.III/ WP.164, 4 ('rules on third-party funding'); Thailand, 'Comments by the Government of Thailand' (11 April 2018), A/CN.9/WG.III/WP.147, para. 18. 
Another option for dealing with the problem of costs is connecting host citizens with not-for-profit legal advocacy organisations. As demonstrated by the frequency with which some of these organisations submit amicus curiae briefs to arbitral tribunals for investor-state arbitrations, ${ }^{115}$ it is apparent that they have the capacity to act in international adjudications. What is also noteworthy is how their involvement has generally taken the form of assistance to local communities in opposition to investors. ${ }^{116}$ But the resources of not-for-profit legal advocacy organisations are finite. Because of this, it is likely that they will be mostly inclined to take on cases that have special symbolic value. ${ }^{117}$ Additionally, if it is the case that only not-for-profit legal advocacy organisations are willing to take cases for host citizens, then the fear is that the international adjudication of host citizeninvestor disputes will serve more as a theatre for ideological battles between these organisations and investors. With such a system, all the battles that need to be fought to deliver justice to all deserving host citizens cannot be fought. For this reason, states will need to consider other options to give host citizens access to justice in respect of their disputes with investors.

\section{Other Options for Facilitating Access to Justice for Host Citizens}

\section{Ombudspersons and Better Access to Domestic Courts}

Drawing inspiration from the Canadian Ombudsperson for Responsible Enterprise, ${ }^{118}$ one option is an international ombudsperson for host citizen-

115 See Sophie Lamb, Daniel Harrison and Jonathan Hew, 'Recent Developments in the Law and Practice of Amicus Briefs in Investor-State Arbitration', Indian Journal of Arbitration Law 5 (2017), 72-92 (92); Eric de Brabandere, 'Amicus Curiae: Investment Arbitration' in: Hélène Ruiz Fabri (ed.), Max Planck Encyclopedia of International Procedural Law (online edn, Oxford: Oxford University Press 2018), para. 3; and Eugenia Levine, 'Amicus Curiae in International Investment Arbitration: The Implications of an Increase in Third-Party Participation', Berkeley J. Int'l L. 29 (2011), 200-224 (209).

116 See, for example, the overview of investment-treaty arbitrations involving amicus curiae submissions in Lamb, Harrison, and Hew (n. 115), 82-85. Indeed, one of the foundational reasons for the institution of amicus curiae submissions into international investment law was to facilitate the participation of local communities in investment-treaty arbitrations, see Katia Fach Gómez, 'Rethinking the Role of Amicus Curiae in International Investment Arbitration: How to Draw the Line Favorably for the Public Interest', Fordham Int'l L. J. 35 (2012), 510-563 (543).

117 Austin Sarat and Stuart Scheingold, 'State Transformation, Globalization, and the Possibilities of Cause Lawyering' in: Austin Sarat and Stuart Scheingold (eds), Cause Lawyering and the State in a Global Era (Oxford: Oxford University Press 2001), 13 ('Cause lawyers choose clients and cases in order to pursue their own ideological and redistributive projects.').

118 For further details, see <https://core-ombuds.canada.ca/core_ombuds-ocre_ombuds/in dex.aspx?lang=eng $>$. 
investor disputes. In common with most other ombudspersons, this official could receive complaints from host citizens, investigate them, and issue recommendations to the host citizen and the investor on a possible resolution. ${ }^{119}$ Hard legal considerations and practical realities, however, get in the way of this starry-eyed idea. Most specifically, without the power to compel the submission of evidence from the disputants, the investigation phase will be meaningless. ${ }^{120}$ In order to compel evidence, an ombudsperson would need some institutional support to enforce his or her orders. What international institution could play this role is unclear.

Another option would be to facilitate the domestic adjudication of host citizen-investor disputes. In the Morocco-Nigeria Bilateral Investment Treaty (BIT), this option was apparently pursued:121

'Investors shall be subject to civil actions for liability in the judicial process of their home state for the acts or decisions made in relation to the investment where such acts or decisions lead to significant damage, personal injuries or loss of life in the host state.'

What this provision exactly means is not entirely clear. On a textual reading, it merely affirms what should already be clear, that investors can be sued in their home states. But it must mean more than this. In the model investment treaty on which the Morocco-Nigeria BIT is based, this treaty provision is meant to operate in conjunction with the following provision: ${ }^{122}$

'Home states shall ensure that their legal systems and rules allow for, or do not prevent or unduly restrict, the bringing of court actions on their merits before domestic courts relating to the civil liability of investors for damages resulting from alleged acts or decisions made by investors in relation to their investments in the territory of other Parties. The host state laws on liability shall apply to such proceedings.'

119 Ross Cranston, 'Ombudsmen' in: Cane and Conaghan (n. 58), 851.

120 This has been the main criticism of the Canadian Ombudsperson for Responsible Enterprise, see The Canadian Press, 'Panellists Quit Corporate Responsibility Panel Citing Erosion of Trust' (Canadian Broadcasting Corporation, 12 July 2019) <https://www.cbc.ca> accessed 11 August 2021.

121 Reciprocal Investment Promotion and Protection Agreement between the Government of the Kingdom of Morocco and the Government of the Federal Republic of Nigeria of 3 December 2016, Article 20.

122 Howard Mann, Konrad von Moltke, Luke Eric Peterson and Aaron Cosbey, IISD Model International Agreement on Investment for Sustainable Development: Negotiators' Handbook (2nd edn, Winnipeg: International Institute for Sustainable Development 2006), Article 31. 
The commentary attaching to this provision confirms that the phrase 'ensure that their legal systems and rules allow for, or do not prevent or unduly restrict, the bringing of court actions' means that home states have to change their rules on the jurisdiction of their domestic courts, ${ }^{123}$ changes which would remove legal barriers to them hearing host citizen-investor cases. These changes ask much of home states. Unless they enact bespoke exceptions for the benefit of host citizens to the generally applicable rules on jurisdiction in civil-liability cases, then states will have to implement wholesale changes to these rules. Additionally, requiring judges to apply the law of the host state, which is what this provision also demands, adds another layer of expense and difficulty in any host citizen-investor case in the home state. Finally, as mentioned in section II.2. above, accessing justice in the domestic courts of home states will presumably be more expensive for host citizens, particularly if the host citizen comes from a developing state and the investor is based in a developed state.

\section{Mandatory Insurance Scheme for Host Citizen-Investor Disputes}

It is becoming apparent that there is no silver bullet for securing access to justice for host citizens in respect of their disputes with investors. A complete rethink is needed, which means going back to the basics. ${ }^{124}$ The first basic fact that needs to be appreciated is that host citizen-investor disputes are tortious in nature. The second basic fact is that the potential number of these disputes is very, very high. The same is true with respect to tortious disputes in domestic legal systems, which prompts the question: how are they resolved there? In developed states, the disputants usually never step near domestic courts. Resolving all of the tortious disputes with courts would cost societies much time and many resources. For this reason, the business of resolving tortious disputes is outsourced - to insurance companies. In developed states, liability insurance is widespread, thereby meaning that claimants in tortious disputes do not file claims to courts, but rather to the insurers of the respondents. ${ }^{125}$ Insurers effectively adjudicate on claimants' claims, although there should always be an option for claimants to complain to courts about these insurers'

123 Mann, von Moltke, Peterson and Cosbey (n. 122), 43.

124 The core message here is that if giving host citizens access to justice on a broad scale is the main goal, then the role of insurance needs to be front and centre of that conversation. For the tendency of tort-law jurists to overlook this leading role of insurance, see Rob Merkin and Jenny Steele, Insurance and the Law of Obligations (Oxford: Oxford University Press 2013), 1.

125 Richard Kurt Lewis, 'The Relationship between Tort Law and Insurance in England and Wales' in: Gerhard Wagner (ed.), Tort Law and Liability Insurance (New York: Springer Publishers), 47-85 (48). 
adjudication. Insurers dispense rough-and-ready justice. Generally speaking, qualified lawyers do not usually go over claims with a fine-tooth comb. The business of adjudication is rather undertaken by non-lawyers and, increasingly, computers. ${ }^{126}$ In the vast majority of cases, insurers pay the claimant some compensation, although the adequacy of their payments is often a contentious point. ${ }^{127}$ Nonetheless, the system delivers justice to claimants on a broad scale and at an affordable price.

The challenge is to replicate this kind of system to resolve host citizeninvestor disputes. The first step towards meeting that challenge is to manufacture a situation where investors habitually take out liability insurance policies in respect of host citizens' claims. One option for this purpose would be to condition access to the MIC, for example, on the conclusion of an insurance policy for the benefit of host citizens. ${ }^{128}$ This could be a standard-form contract drafted by a body under the auspices of the MIC, a body which should be composed of representatives for the beneficiaries (host citizens), the insurers, and the policy-holders (the investors). It would operate as any other insurance policy: the policy-holder would pay a premium in return for the insurer agreeing to cover its international liability towards host citizens. If the system functions as the equivalent systems in domestic legal orders function, then insurers will efficiently conduct the necessary adjudication of host citizen-investor disputes, and presumably most host citizens will receive the compensation owing to them. If a host citizen was dissatisfied with this process, he or she could bring a claim before the MIC. The MIC could act as a last-resource enforcement mechanism. Adjudications performed by the MIC will be expensive, but their number should be small and host citizens might make use of successful fee arrangements with their lawyers or find assistance through not-for-profit legal advocacy organisations.

\section{a) Legal Issues}

Standing in the way of these plans, however, are some legal issues. They relate to the identity of the insurer and the policy-holder. As regards the identity of the insurer, the concern is their financial fitness to offer the

126 Ramnath Balasubramanian, Ari Libarikian and Doug McElhaney, 'Insurance 2030 - The Impact of AI on the Future of Insurance' (McKinsey \& Company, 12 March 2021) <https:// www.mckinsey.com/> accessed 11 August 2021.

127 Lewis (n. 125) 49.

128 The legality of this obligation is not in question because it would act as a condition to accessing the MIC and such obligations are recognised as valid under the law of treaties, see Vienna Convention on the Law of Treaties of 23 May 1969, 1155 UNTS 331, Art. 36(2). 
envisioned insurance policies. ${ }^{129}$ Assessing their financial fitness is not work that MIC should be conducting. The better option is to rely on qualification tests done by domestic authorities; in other words, if an insurer is licensed under domestic law, then it should also be licensed to sell this insurance product. But under which domestic law should it hold a license? Generally, a state's regulations on licensing of insurers are triggered if an insurer offers its insurance products to putative policy-holders who are resident in that state. ${ }^{130}$ Because of this general position, investors will usually have to conclude insurance policies with insurers which are licensed in their home state, thereby meaning that if an insurer is licensed there, then it is licensed to sell insurance policies for international liability arising out of host citizen-investor disputes. The complication is that this insurance policy is a third-party insurance policy. For this reason, the host state has an interest in the financial health of the insurer, remembering that its host citizens are the third-party beneficiaries. Because of this interest, insurance regulators in the host state might insist that the insurer also be licensed under its law, a result that would severely limit the number of eligible insurers and, by extension, would threaten the viability of the system. This situation cannot come to pass. States that sign the treaty creating the MIC would have to agree that if an investor purchases an insurance policy from a licensed insurer in its home state, then the insurer will not face additional regulatory difficulties in the host state.

Another issue is the identity of the policy-holder (the investor). As explained in section IV.1. above, it is considered that only 'controlling investors' should have liability towards host citizens, thereby meaning they should take out an insurance policy. Some definitions of 'controlling investor' were proposed in that section as well. In most cases, these definitions should be able to identify whether an investor is a controlling investor or not, which deductively means that, in some cases, their application will not be clear. This is a weakness of the system. As the definition of 'controlling investor' becomes clearer over time, this problem will begin to dissipate. Until then, investors will have to rely on the advice of their lawyers.

\section{b) Practical Issues}

In addition to these legal issues, there are several practical issues that would have to be considered when establishing this system of mandatory

129 Merkin and Steele (n. 124), 77 ('Insurance calls for regulatory intervention more than almost any other class of commercial operation.').

130 Merkin and Steele (n. 124), 81. 
insurance. As comprehensively resolving these issues is beyond the scope of this paper, these issues are only flagged here.

The first issue relates to the feasibility of valuing investors' liability risks. ${ }^{131}$ Remembering that investors would take out insurance policies with insurers in their home states with respect to risks in the states hosting their investments, some insurance companies might feel that they cannot value the risk that they are taking. If this problem materialised, then it would naturally limit the market of potential insurance-providers for investors. A second issue concerns host citizens' capacity to file a claim under the insurance policies. Not only do host citizens need to be made aware of them, but the filing procedure must be as simple as possible. Investors will have to play a large role here. When an incident involving harm to a host citizen does occur, it should be obliged to inform him or her that he or she can claim compensation under its insurance policy. This obligation might be codified as a treatybased investor obligation. A third issue is insurance fraud. Insurers rely on criminal justice systems to prosecute perpetrators of insurance fraud. While they can always reject fraudulent claims, criminal prosecutions of such claims have a deterrent effect that mere rejection cannot match. Accordingly, the host state has an important role to play in this system by prosecuting insurance fraudsters.

\section{Conclusion}

These problems are not insurmountable. For this reason, the basic conclusion is that if the jurists of international investment law want to deliver justice in host citizen-investor disputes on a broad scale, then a mandatory insurance scheme has to play the leading role. The MIC would play a supporting role. Although designing the MIC for it to accommodate the adjudication of host citizen-investor disputes would present challenges, all of them can be overcome. As regards the legal challenges, the most serious one is the applicable substantive law. It is considered that the adjudicators of the MIC would have to develop an autonomous body of international law for this purpose. The other major challenge is the cost. Experience with other international courts shows that international adjudication is invariably expensive. For the Jacklike claimant who was encountered in section II., it will probably be beyond

131 Michelle Everson, 'Regulating the Insurance Sector' in: Niamh Moloney, Eilís Ferran and Jennifer Payne (eds), The Oxford Handbook of Financial Regulation (Oxford: Oxford University Press 2015), 411 ('Successful pooling of risk is a technical feat which is wholly dependent upon informational completeness and actuarial exactness.'). 
his or her means. Considering that the international adjudication of host citizen-investor disputes would be instituted for the benefit of such claimants, this is a problem that states cannot ignore.

The core of this problem can be dealt with by instituting the mandatory insurance scheme outlined in section V.2. Fundamentally, this scheme would create a system of adjudication that would run parallel to the formal system under the MIC. It could deliver justice to host citizens at an acceptable cost, while the MIC would be used on the rare occasion that this system fails the deserving host citizen or the insurers need further clarification from the MIC adjudicators on the extent of investors' tortious liability towards host citizens. All of the details on how this system would function have not been put forward here, but rather an idea has been put on the table. It is now for others to take it and shape it. 